\title{
The New Control of Territory and Urban Planning: The Eminent Domain in the US
}

\author{
Sonia Paone ${ }^{1}$ \\ ${ }^{1}$ Department of Political Science, University of Pisa, Pisa, Italy \\ Correspondence: Sonia Paone, Department of Political Science, University of Pisa, Pisa, Italy.
}

Received: January 22, 2018

Accepted: February 19, 2018

Available online: March 12, 2018

doi:10.11114/ijsss.v6i4.2942

URL: https://doi.org/10.11114/ijsss.v6i4.2942

\begin{abstract}
The article analyses the transformations of the use of eminent domain in the United States in the context of urban redevelopment programs. In the past the private property has been expropriated for public use only. Recently it is possible to forcibly transfer property, from a private subject to private developers, on the basis of a cost-benefit analysis that demonstrates that the new use is more efficient than the previous one. This profound change has been possible thanks to a progressive modification of the concept of public use. Traditionally, public use coincided with the construction of infrastructures and public utility, such as highways and railroads. Over the time, it has come to include other aims: firstly, projects of urban renewal and economic development carried forth by private developers. Essentially, it has resulted in the use of expropriation to assemble lands which are then granted to subjects who intervene in the reconfiguration of the city for private purposes. Starting from some important examples of urban development, the main phases of this process are reconstructed, also taking into account the most important decisions of the US Supreme Court that contributed to the change of doctrine, invalidating the postulate of public use as justification for expropriation.
\end{abstract}

Keywords: territory, urban planning, eminent domain, private property, urban redevelopment, urban policy

\section{Introduction}

In the United States, the so-called Eminent Domain is the power of state or federal government to take private property for public use. The roots of this instrument reach back to English feudal law, which recognised the king's supreme power over all lands of the kingdom. The expression 'eminent domain' is attributed to Hugo Grotius. In the American Constitution, the state has the natural right to control private property for higher purposes. Protecting the private subject, the Fifth Amendment of the Constitution indicates the manner in which expropriation must take place, determining that the government shall not take private property for public use without paying just compensation (takings clause). Traditionally, expropriation had the objective of constructing infrastructure, collective services, constraining the taking of private property to the creation of spaces whose use was intended exclusively for the society as a whole. Over the years, however, the concept of public use has been changing and has been increasingly understood as being synonymous with public purposes and aims, expanding both the possibilities of expropriation and those of intervention by private developers that thus become part of the city's governance on the assumption of a presumed collective benefit.

In the last 50 years, the use of eminent domain in the United States, in the context of strategies of urban redevelopment, has changed. The progressive change of the concept of public use can be reconstructed by taking into account a number of Supreme Court decisions that have arisen following disputes concerning expropriation (Epstein 1985). Redevelopment projects involve land acquisition and disposition of the land to private developers who rebuild the area according to a comprehensive plan. In this sense, the law of eminent domain is an important tool for city planning. In the past the private property has been usually expropriate for public use only: the construction of infrastructures and public utility The power of eminent domain has been used to facilitate the building of highways, schools, hospitals, and other structures vital to the welfare of the people and the state. In the recent years -after the famous Supreme Court decision of Kelo versus New London in 2005- it is possible to transfer land from one private owner to another one to further economic development. Substantially, it is constitutional for government to use its power to buy private property and turn that property over to another private interest. The article reconstructs the main stages of the expansion of power of eminent domain starting form the first important modification of use of eminent domain related with the redevelopment project of District of Colombia in Washington D.C. The District of Columbia attempted to use eminent 
domain to purchase private areas of land for the purpose of regeneration. The court ruled that revitalizing a depressed neighbourhood served a public good, and therefore qualifies as a "public use". With this decision, the Supreme Court decided that the concept of public use should have been expanded in order to include public purpose. The second part of the article shows the increasing use of eminent domain for economic development reporting the case of two important redevelopment project: the revitalization of Poletown neighbourhood in Detroit and the revitalization of Fort Trumbull Peninsula in New London.

\section{From Public Use to the Public Purpose: Eminent Domain and Urban Renewal}

The progressive modification of the concept of public use is linked to strategies for the development and requalification of entire parts of the city through infrastructure projects, the relocation of productive activities and of populations, the demolition of existing structures and regeneration of deprived urban areas. The period of implementation of these policies was already underway by the early decades of the $20^{\text {th }}$ century, with the promotion of a series of major projects for bridges, roads and spaces for collective services. An important area of interventions concerns the improvement housing standards through slum clearance, or the restoration of housing in poor and dilapidated neighbourhoods. For example, the Housing Act of 1937 had the specific objective of helping the States offer a remedy to the poor housing conditions of low-income families, thereby ensuring decent housing.

Another important step of the housing policy is the promulgation of the Housing Act of 1949, the measure by which federal funds were allocated for the purchase of slum areas where new homes were to be built by private developers. In 1954 a subsequent Housing Act further facilitated construction, also through the granting of mortgages, opening up a phase of great transformation in the cities that take the name of urban renewal. This expression refers to all public policies that, from the second half of the 1950s, have aimed at redeveloping dilapidated or no longer functional urban areas in American cities (Gelfand 1975; Teaford 1990; Wilson 1966; Andersen 1964).

\subsection{The Washington Southwest Redevelopment Project}

It is in this context that the concept of public use began to change, and consequently the possibilities and modes of property expropriation. More specifically, the reconceptualization of public use is linked to the redevelopment project of the Southwest area of Washington in the early 1950s- In fact, the District of Columbia Redevelopment Act of 1945, under which renewal was carried out, came in an important way to be prototypical of future federal redevelopment legislation. Moreover, the opinion of the Supreme Court in the case of Berman v. Parker validated and interpreted the Act, and became the crucial precedent for the use of the power of eminent domain (Ginsberg 1971; Lavine 2010).

Awareness of the issue of very poor hygiene-sanitary conditions in housing in various parts of Washington had existed since the 1940s, with some measures and appropriations for funds already being undertaken to improve the salubriousness of the housing. In 1950, the National Capital Planning Authority had developed a comprehensive plan for the District of Columbia, and only in 1952 was the so-termed Southwest Redevelopment Area selected for redevelopment:

"The so-called Southwest Redevelopment Area was immediately to the south of the Capitol, bounded by the Mall, South Capitol Street, the Washington Channel, and the Anacostia River. The first tract selected for redevelopment, called Project Area B, was said to contain some of the worst housing in the District of Columbia. The project area covered seventy-six acres, $35 \%$ of which were to be devoted to residential use, $5.8 \%$ to commercial use, and $14 \%$ to public and semi-public use. $64.3 \%$ of the dwelling units in Area B were considered substandard in terms of facilities, maintenance, and occupancy; and 79.7\% were substandard on the basis of deterioration. The area's income level was considerably below the city average, and its death and disease rate considerably above that average. $97.5 \%$ of the area's slightly under 10,000 inhabitants were Negro" (Ginsberg 197, p.56)

Substantially, most of the housing stock was considered to be below the minimum living standards and on the basis of the assessments, it proved cheaper to demolish them, which would result in its re-modernisation. In Area B, 57.8\% of the homes did not have inside toilet, $31.3 \%$ had no inside running water, $82.2 \%$ had no washbasin or installed laundry tub, 29.3\% had no electricity installed and $83.8 \%$ did not have central heating. The level of income was lower than the average in the city, whereas the rate of mortality and illness was significantly higher (Lavine 2010). The plan included provisions for potential future low-income and/or minority ethnicity residents. In fact, it required that "one-third of the housing be designated for low- income families with rents not exceeding \$17 per room per month, excluding utilities" and that "there be appropriate covenants running with the land with respect to the prohibition of restrictions upon the sale, lease, or occupancy of any land or real property in the Project Area on the basis of race, colour, or creed" (United States National Capital Planning Commission 1952).The disposition of a neutral housing policy in relation to race was maintained on paper - even if the opposite actually happened, as we will see - whilst the requirement of the $\$ 17$ limit was eliminated. The revocation was based on several considerations, including cost increases that made the $\$ 17$ limit unrealistic and the absence of Federal housing legislation that would make the construction of housing for 
lower-middle-income families economical (Lavine 2010)

The implementation of the plan involved the expropriation of the majority of the properties present within the area of the redevelopment project and the subsequent intervention of private investors.

\subsection{Eliminating Blight: The Beautification of the City}

In December 1952, two owners of commercial spaces (a hardware store and a large warehouse) located on the 700 block of Fourth Street, belonging to Area B, contested the expropriation of their property. Above all, they argued that the Housing Act of 1949, which had inspired the intervention plan in Southwest Washington, was a law concerning housing and therefore did not concern the conditions of commercial or productive property. Moreover, if the property was repossessed and destined for private use for the purposes of private entrepreneurs that could have exploited the area, it could not be considered public use and on this basis the plan violated the Fifth Amendment of the Constitution, which - as stated - established expropriation for public use only. Finally, the applicants contested to the valuation of the state of the properties of Area B. If the criteria which defined the housing stock's in salubrity and below the minimum living standards was very clear, the concept of blighted, which was presupposition in the plan for the expropriation of the commercial properties - was rather vague and generic (Lavine 2010; Ginsberg 1971).

Substantially, the applicants objected that the expropriation for a project whose sole purpose was to render the area more attractive, and which would benefit private entrepreneurs, could not be considered public use (Gillette 1995). The Court, on the other hand, expressed its support for the Planning Commission with a historic decision that amplified the concept of public use by extending its meaning to public purpose as a justification for the expropriation, and was not therefore prejudicial to the Fifth Amendment.

In the words of the Court, in this case the public purpose was based on physical, aesthetic and monetary benefits connected to an urban rehabilitation plan aimed at intervening in dilapidated areas or preventing their decline: "The concept of public welfare is broad and inclusive. The values it represents are spiritual as well as physical, aesthetic as well as monetary. It is within the power of the legislature to determine that the community should be beautiful as well as healthy, spacious as well as clean, well-balanced as well as carefully patrolled. In the present case, the Congress and its authorised agencies have made determinations that take into account a wide variety of values. It is not for us to reappraise them. If those who govern the District of Columbia decide that the Nation's Capital should be beautiful as well as sanitary, there is nothing in the Fifth Amendment that stands in the way."(Berman vs. Parker 348 US 1954).

The Court also ruled that once the issue of public purpose was defined, it was at the discretion of the legislative branch to decide which and how many areas to expropriate.

The Berman vs. Parker decision constitutes an important change in expropriation in that it broadens the opportunities for acquisition in favour of projects that back the interests of private investors. However, an even more important socially consequential aspect is the vague concept of blighted. A brief digression is required here, as it is necessary to specify that the urban decline terminology was already determined in US public debate in the decades before the Berman vs. Parker thanks to the increasing attention of planners, architects and administrators to the terms slum and blight. The planners and architects had put together a complex lexicon to demonstrate the danger of these two urban conditions. Slum was defined as a mostly inhabited area where the poor structural conditions of buildings (overcrowding, a lack of hygienic-sanitation systems, lack ventilation) constituted the ideal environment for the spread of crime and immorality, hence it was the community's responsibility to intervene with restoration programmes (Gordon 2003). Other areas without the same characteristics of a slum were considered equally dangerous as they were considered to be blighted. The term 'blight', used in urban areas since the Chicago School, originates in biology and describes a plant disease. In a work by Mabel Walker of 1938, the term is specifically associated with certain characteristics of the city, and defined as urban blight: an area in which deterioration has led to the reduction of economic and social values up to a degree that requires the intervention of widespread redevelopment to avoid transformation into slums (Walker 1938; Pritchett 2003). Blighted is a condition that precedes that of a slum, and since the term originally describes a plant disease, it is evoked in the urban sphere to create the idea of a kind of plague that, if not addressed and removed, can either spread from one neighbourhood to the next, or worsen by transforming the area into a slum (Gibson 2003, Wilson 1996). In this perspective, the future of the city depended on the efforts enacted to stop the disease by cleaning up and reconstructing the entire area considered to be blighted, thus avoiding healthy areas becoming affected (Beauregard 2003).

Concern for the blighted areas was not simply that they could become a slum, but that they represented an obstacle for the city's growth. It is interesting to note how the issue of an urban space's degradation was addressed by referring to a concept of urban quality based on the opposition of blighted and healthy. This scientific-like vision naturalised the social phenomena and presented the intervention as necessary in the form of urban beautification (Gillette 1995), yet the brutal reality of the concept of blight was constructed in America with clearly-defined goals. The word 'blight' is 
deliberately vague and, in fact, has been transformed into a device used to reorganise ownership regimes, encouraging private investors and elites at the expense of minorities.

In fact, blight is an apparently neutral word and a façade often used in the concrete analysis of city conditions to describe the negative impact of the presence of certain types of residents within neighbourhoods. In urban planning practices, the assessment of blighted areas has turned out to be a sort of 'scientific' method for constructing urban decline that has justified the removal of Afro-Americans and other minorities from important parts of the city (Pritchett 2003). By using race as a selective criterion for declaring blighted areas which needed to be restored because they were dangerous for the entire urban body, redevelopment projects such as the one under examination enabled the institutional and political elites to reallocate minorities by favouring racial segregation. Despite the dispositions protecting low-income families and the alleged neutrality in relation to the issue of race, for example the Washington Redevelopment Plan turned out to be a brutal operation for distancing families of colour.

A comparison of census data in Area B before and after the redevelopment undertaken in 1950 and 1960 is enlightening: the total population of the area was down by nearly 8,000 units. The white population rose by 159 units and the average income increased by $\$ 3,000$. The number of housing units occupied by black persons had dropped by about 1,900 units. Of the 183 housing units that housed black people in 1960, 120 were grouped into public houses located in one stretch at the southern end of the area. The area was thus transformed from residential - with the prevalence of black and poor households - into a low-populated area with high incomes and practically only white occupants, except for the three confined southern blocks (Ginsberg 1971). The centrality of race in the definition of blight can also be seen in the case of Los Angeles where, in 1950, the City Planning Commission designated eleven areas as blighted and all but one had a population comprised of Mexicans and Afro-Americans (Alexander and Bryant 1951). Similarly, in Chicago, the blighted instrument was used to avoid the expansion of the black ghetto in the late-1940s (Hilmann and Casey 1950; Hirsch 1983) ${ }^{1}$. The Berman vs. Parker decision, which considered the restoration of the blighted areas as public purpose and left the designation of these 'sick' areas to the discretion of the local government substantially favoured the interests of private investors and contributed little to rendering the urban renewal programmes more than mere, so-called "Negro Removal" operations. On the other hand, it should be remembered that between 1950 and 1960, American cities implemented massive redevelopment projects, especially in the areas around its central business districts, and this resulted in the displacement of more than one million people, mostly belonging to minorities (Pritchett 2003).

\section{The Entrepreneurial City: Eminent Domain and Economic Development}

In this path of changing urban policies and case laws concerning property use, another important step was the dispute resolved by a similarly famous Supreme Court decision in the case Poletown Neighbourhood Council vs. City of Detroit of 1981. In the wake of what was determined in the Berman vs. Parker case, the court's decision further extended the concept of public purpose by establishing the legitimacy of expropriation for economic development projects in areas not necessarily considered blighted.

\subsection{Detroit: Private Purpose and Public Intervention}

In this particular case, the city of Detroit had requested the acquisition (through expropriation) of an entire neighbourhood, with the aim of selling the land thus acquired to General Motors for the construction of a new plant. It was therefore a transfer of individual property to a private company. General Motors had decided to shut down an obsolete plant in Detroit and sought another location for the construction of a new, more modern establishment.

To stave off job losses, the city of Detroit decided to sell General Motors an area of the city for the new production facility at a low cost. The area identified for this operation was the Poletown neighbourhood, so named because since the early- $20^{\text {th }}$ century it had accommodated nearly fifty thousand immigrants from Poland, the most famous of which was anarchist Leon Czolgosz, who assassinated President William McKinley in 1901.

At the beginning of the 1980s and thus at the time of the Poletown dispute, around half of the area was inhabited by Afro-Americans in a context where the industrial economy which had been seen as Detroit's strength had long been in crisis. The city's main automotive industry had begun to shrink after the mid-1950s: Chrysler lost 23,000 jobs between 1955 and 1958, and in the same period the Packard Motor Car Company closed, Hudson merged with Nash and subsequently transferred its production to Wisconsin, causing the loss of 35,000 jobs in Detroit (Michigan Bar Journal 2009).

Thanks to these continuing crises, by 1980 unemployment in the city was $18 \%$. Economic problems were accompanied by a sharp decline in population: in the 1950s the city lost $10 \%$ of the population; in the 1960s, another $9 \%$ left, with this haemorrhage continuing throughout the 1970s and 1980s. In this context of tension and crisis at the beginning of

\footnotetext{
${ }^{1}$ On the ratio of urban renewal and the racial segregation of Afro-Americans, see also R. Bayor (1966); T. Sugrue (1996).
} 
the 1980s and, as we recalled, in order to avoid the additional closure of a General Motors production plant, the Detroit mayor negotiated with the company in order to expand its occupation in the city. General Motors expressed its will to construct a new Cadillac assembly plant, provided that the city could quickly provide a 500-hectare site with adequate infrastructures in terms of road and rail transportation, and that a tax abatements plan would be established. The designated area was the Poletown district that, in the early 1980s, included over 6,000 residents, 1,400 houses, 144 businesses, 16 churches, two schools and a hospital.

Between compensation for the expropriation and a series of improvements requested by General Motors, the planned cost for the city was $\$ 200$ million. The new plant would employ 6,000 people, in addition to thousands of jobs related to its construction, yet all this would not compensate for the loss of employment due to the closure of two other General Motors plants (Michigan Bar Journal 2009). Various residents appealed to Michigan's Supreme Court against the expropriation, arguing that it was an operation for a private corporation and thus not related to issues of public use, also considering, inter alia, that the areas subject to expropriation had not been declared blighted.

The Court expressed its support for the Poletown intervention plan and established above all, in line with the Berman vs. Parker decision, that the capabilities of the state government had no limits in its decisions and strategies to improve the economic outcomes of the cities. Moreover, in the opinion of the Court, if the legislature maintained that public support for an economic development operation was necessary, this was sufficient to satisfy the premise of public use. The power of expropriation must be used to achieve a public purpose that is essential for alleviating and revitalising a community's economic base, with the benefit of the private company in this case being merely accidental.

\subsection{Urban Revitalization and Private Business: The Kelo vs. New London Decision}

The Poletown case therefore inaugurated a new era in urban renewal policies where the link between public and private became ever stronger and where expropriation continued to be emptied of public purpose in favour of private interests linked to presumed objectives of economic development, regardless of an assessment of the conditions of the area to be expropriated. In order to better understand the situation in Detroit, it should also be remembered that the Poletown decision was from 1981, that is, at the beginning of a decade of profound change in urban policies triggered by the process of deindustrialisation and delocalisation of production.

Hence, it was a period that marked the Fordism crisis and the dawn of globalisation. Industrial relocation has profoundly affected urban dynamics in all those contexts -and in fact throughout the entire United States-where industry had been the heart of many cities' success and strength (Mollenkopf \& Castells 1991). As the Detroit case also illustrates, the shift of entire production sectors and the consequent haemorrhaging of jobs in the primary sector marked the beginning of a major crisis in the urban entities that had developed on an industrial basis. At the same time, at the end of the 1980s, the acceleration of internationalisation and financialisation processes quickly allocated new economic activities to the cities able to concentrate control, financing and management operations (Sassen 2007), also favoured also by the interaction possibilities arising from new technologies.

In this fast-moving scenario, there was an increase in competition between cities in an attempt to attract flows and thus be positioned in the new urban power scheme. All of this involved a new season of revitalizing of the cities (Hall 2002) based on major regeneration/requalification projects and, more generally, on policies that focused more and more on the construction of an attractive and innovative urban space, testifying a neo-liberal turn in urban policies (Hackworth 2007; Brenner and Theodore 2002).

The hypothesis of a neo-liberalisation of urban policies is strongly linked to the crisis of the Fordist-Keynesian model, and hence to the decline of the accumulation regime that characterised the decades after the post-war era based on complementarity between mass production and consumption and highly-dependent on state intervention in order to function (economic policies encouraging productive investment, redistributive spatial policies, social security policies). Since the 1980s, development of location policies has taken place, aimed at attracting enterprises and solvable groups in a context of increased interurban competition (Brenner 2004).

In addition, the forms of government of the territory were modified with the transition from a public-managerial to one of an entrepreneurial approach. The first approach is defined as Harvey government and refers to a style of management based on the primacy of the public sector and the redistribution policies of locally-produced resources. The second approach is instead defined as governance and involves more decentralised forms of territorial governance and the loss of public supremacy.

Governance is characterised by the increasing influence of public-private coalitions in the fulfilment of major urban regeneration and renovation projects, and government-led decision-making processes involving various actors, including private developers (Harvey 1989). Two spatial devices are central to this: creating areas that are functional for the entertainment industry (themed restaurants, hotels and convention centres, event and exhibition halls) and the 
construction of quality residential areas (Harvey 1993). The target these proposals were directed to increasingly included the elite of the emerging global class whose lifestyle was fuelled by consumption (Zukin 1995; Hannigan 1998; Milton 2009). As a result of these changes, which were already present in the Detroit dispute, the courts further modified the regime of expropriation, once again in favour of private intervention in a city's design. The last decision we will refer to was emblematic of this further change: the case of Kelo vs. New London of 2005. New London is a city based on the Thames River which had been prosperous in the industrial era thanks to its port. Its economy and wealth were strongly tied to the presence of the Naval Undersea Warfare Center located on the Fort Trumbull Peninsula.

The centre closed its doors in 1995, leading to a period of decline for the city due to the significant loss of jobs. The government then decided to establish a plan to regenerate the city to ward off a definite crisis. In 1998, the New Development Corporation, a public-private coalition commissioned to work on the regeneration project, convinced the pharmaceutical multinational Pfizer to select New London as the site for its new research facility. The city would offer the multinational part of the waterfront free of charge, whilst the New Development Corporation would utilise state funds for acquisition via expropriation of the aforementioned property, and would arrange for the subsequent demolition of residences and industrial sites located on the Fort Trumbull Peninsula. The project was very ambitious and included the construction of a park, commercial and tourist facilities, a marina and new residences (Solmyn 2015).

In essence, a complete renovation was drafted for the entire area where the Naval Undersea Warfare Center originally stood. However, the project failed miserably. The architectural and infrastructural component was never completed and in 2009 Pfizer decided to close the New London plant - also due to the financial crisis that commenced in 2008 -leading to a loss of 1,400 jobs (Niedt 2013). This urban development plan has been relegated to the past not so much because it was a colossal failure, but because of a dispute that was connected to eminent domain. Certain owners within the Fort Trumbull area objected to the legitimacy of transferring property to private developers. The court did not accept the request of the prior owners, arguing that private projects favouring the economic development of declining areas (Brief of Respondents Kelo vs. New London 2005) are to be considered as a public benefit.

It was maintained that expropriation did not prejudice the Fifth Amendment when an economic development plan promises to create thousands of jobs, increase tax-related revenues and generally benefit the city and its residents. The Supreme Court thus ruled that the mere purpose of economic development, as well as the hypotheses related to possible private investments, is sufficient to justify expropriation: the public essentially considers private ends as a public good. At this point, the Kelo vs. New London decision had completely freed up the mechanisms of the neoliberal principles of local government, as the objective of economic valorisation carried forth for private ends as a recipe for development of the city.

\section{Conclusion}

The history of the power of eminent domain contributes to a clearer understanding of the benefits and consequences of the redevelopment programs in United States. Urban revitalization is as a contradictory process: it tries to eliminate the urban decay and the governments have implemented revitalization programs to increase social, economic and political growth and stability and prosperity. On the other hand, the revitalization has generated processes discriminative to poor urban areas. The vague concept of blight has favourite the private business, thanks to the government's possibility to obtain private property by the use of the eminent domain and permitting private redevelopers to purchase the property. Moreover, for decades, local governments have used the eminent domain to condemn areas dominated by racial and ethnic minorities and immigrants. Further contradictory are the consequences of the Kelo decision. The possibility to grab one citizen's property and hand it to another simply because the new owner will generate more revenue from it empties the word 'public' of any important content. Kelo has only expanded power of the private development corporations in urban planning, as governments do not need to demonstrate any redevelopment project for the property in the near future. Some simply began to condemn property with the intent of create shopping malls or luxury hotels. Local governments use eminent domain to target specific projects because of a perception that the local area suffers from a lack of growth. All of these economic development tools, however, are unlikely to lead to an overall increase in societal welfare because the eminent domain simply involves a transfer of income from one group to another. The transformations of eminent domain testify to the existence of private use of a legal instrument that is theoretically aimed at safeguarding and extending the common good. Hence, the "history" of the eminent domain offers important reflections on the debate of the city as a common good. At the same time after the Kelo decision, the forcible exit of small-scale owners to make room for the interests of big private corporations again shows the tendency to multiply the expulsion processes which, as Saskia Sassen (2014) maintains, always characterise the operation of advanced capitalism.

\section{References}

Alexander, R. E., \& Bryant, D. S. (1951). Rebuilding a City: A Study of Redevelopment Problems in Los Angeles, Los 
Angeles: Haynes Foundation.

Andersen, M. (1964). The Federal Bulldozer: a Critical Analysis: 1949-1962, Cambridge: Mit Press

Bayor, R. (1966). Race and the Shaping of Twentieth-century Atlanta, Chapel Hill: University of North Carolina Press.

Beauregard, R. A. (2003). Voice of Decline, the Post-war Fate of US Cities, London: Routledge.

Brenner, N. (2004). New State Spaces: Urban Governance and the Rescaling of Statehood, Oxford: Oxford University Press. https://doi.org/10.1093/acprof:oso/9780199270057.001.0001

Brenner, N., \& Theodore N. (eds.) (2002). Spaces of Neoliberalism: Urban Restructuring in North America and Western Europe, Blackwell, Oxford. https://doi.org/10.1002/9781444397499

Epstein, R. A. (1985). Private Property and the Power of Eminent Domain, Cambridge: Harvard University Press.

Gelfand, M. I. (1975). A Nation of Cities: the Federal Government and Urban America 1933-1965, New York: Oxford University Press.

Gibson, T. A. (2003). The Trope of Organic City. Space and Culture, 6, 429-448. https://doi.org/10.1177/1206331203253204

Gillette, H. (1995). Between Justice and Beauty: Race, Planning and the Failure of Urban Policies in Washington DC, Baltimore: John Hopkins University Press.

Ginsberg, B. (1971). Berman vs. Parker: Congress, the Court \& Public Purpose. Polity, 1, 48-75. https://doi.org/10.2307/3234064

Gordon, C. (2003). Blighting the Way: Urban Renewal, Economic Development, and the Elusive Definition of Blight. Fordham Urban Law Journal, 31, 305-337.

Hackworth, J. (2007).The Neoliberal City: Governance, Ideology, and Development in American Urbanism, Ithaca: Cornell University Press.

Hall, P. (2002). Cities of Tomorrow: An Intellectual History of Urban Planning and Design in the Twentieth Century, Oxford: Blackwell.

Hannigan, J. (1998). Fantasy City: Pleasure and Profit in the Postmodern Metropolis, London: Routledge.

Harvey, D. (1989). From Managerialism to Entrepreneurialism: The Transformation in Urban Governance in Late Capitalism. GeografiskaAnnaler B., 1, 3-17. https://doi.org/10.1080/04353684.1989.11879583

Harvey, D. (1993). La crisi della modernità, Milan: Il Saggiatore.

Hillman, A., \& Casey, R. J. (1953). Tomorrow is Chicago, Chicago: Chicago University Press.

Hirsch, A. R. (1983). Making the Second Ghetto: Race and Housing in Chicago 1940-1960, Cambridge: Cambridge University Press.

Lavine, A. (2010). Urban Renewal and the Story of Berman vs. Parker. The Urban Lawyer, 20, 423-475.

Michigan Bar Journal. (2009). Poletown Neighbourhood v. Detroit. Supplement for Michigan Supreme Court Historical Society

Milton, A. (2009).Ground Control: Fear and Happiness in the Twenty-first-century City, London: Penguin.

Mollenkopf, J. H., \& Castells, M. (eds.) (1991). Dual City: Restructuring New York,New York: Russell Sage Foundation.

Niedt, C. (2013). Legal Geographies-The Politics of Eminent Domain: From False Choices to Community Benefits. Urban Geography, 8, 1047-1069. https://doi.org/10.1080/02723638.2013.819683

Pritchett, W. E. (2003). The Public Menace of Blight: Urban Renewal and the Private Uses of Eminent Domain. Yale Law \& Policy Review, 21, 1-52.

Sassen, S. (2007). A Sociology of Globalization, New York: Norton and Co.

Sassen, S. (2014). Expulsions. Brutality and Complexity in the Global Ecomomy, Cambridge: Harvard University Press. https://doi.org/10.4159/9780674369818

Solmyn, I. (2015). The Grasping Hand, Kelo vs. New London and the Limits of Eminent Domain, Chicago: University of Chicago Press.

Sugrue, T. (1996). The Origins of the Urban Crisis: Race and Inequality in Post-war Detroit, Princeton N.J: Princeton University Press.

Supreme Court of the United States. (1954). Decision Berman vs. Parker 348 u.s. 22 
Supreme Court of the United States. (2005). Brief for Respondents at 8, No. 04-108, Kelo vs. City of New London, 545 u.s. 469.

Teaford, J. (1990). Rough Road to Renaissance: Urban Revitalization in America 1940-1985, Baltimore: Johns Hopkins University Press.

United States National Capital Planning Commission. (1952). Redevelopment Plan; Southwest Redevelopment Project, Area B; A report of Existing Conditions and a Planfor Development Adopted on October 24, 1952 Washington, D.C.

Walker, M. (1938). Urban Blight and Slums: Economic and Legal Factors in their Origin, Reclamation and Prevention, Cambridge: Harvard University Press.

Wilson, D. (1996).Metaphors, Growth Coalition Discourses, and Black Poverty Neighbourhoods in US City. Antipode, 28, 72-96. https://doi.org/10.1111/j.1467-8330.1996.tb00672.x

Wilson, J. Q. (1966). Urban Renewal: the Record and the Controversy, Cambridge: Mit University Press.

Zukin S. (1995). The Cultures of Cities, Cambridge: Blackwell.

\section{Copyrights}

Copyright for this article is retained by the author(s), with first publication rights granted to the journal.

This is an open-access article distributed under the terms and conditions of the Creative Commons Attribution license which permits unrestricted use, distribution, and reproduction in any medium, provided the original work is properly cited. 